\title{
Projected pH reductions by 2100 might put deep North Atlantic biodiversity at risk
}

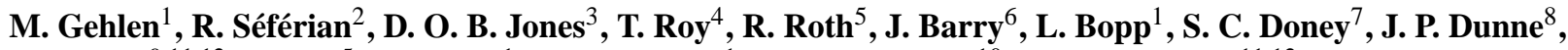 \\ C. Heinze ${ }^{9,11,12}$, F. Joos ${ }^{5}$, J. C. Orr ${ }^{1}$, L. Resplandy ${ }^{1}$, J. Segschneider ${ }^{10}$, and J. Tjiputra ${ }^{11,12}$ \\ ${ }^{1}$ LSCE/IPSL, Laboratoire des Sciences du Climat et de l'Environnement, Orme des Merisiers, \\ CEA/Saclay 91198 Gif-sur-Yvette Cedex, France \\ ${ }^{2}$ CNRM-GAME, Centre National de Recherche Météorologique-Groupe d'Etude de l'Atmosphère Météorologique, \\ Météo-France/CNRS, 42 Avenue Gaspard Coriolis, 31100 Toulouse, France \\ ${ }^{3}$ National Oceanography Centre, University of Southampton Waterfront Campus, European Way, \\ Southampton, SO14 3ZH, UK \\ ${ }^{4}$ LOCEAN/IPSL, 4, place Jussieu 75252 PARIS Cedex 05, France \\ ${ }^{5}$ Climate and Environmental Physics, Physics Institute and Oeschger Centre for Climate Change Research, \\ University of Bern, 3012 Bern, Switzerland \\ ${ }^{6}$ Monterey Bay Aquarium Research Institute, Moss Landing, CA 95039, USA \\ ${ }^{7}$ Marine Chemistry and Geochemistry, Woods Hole Oceanographic Institution, Woods Hole, MA 02543, USA \\ ${ }^{8}$ National Oceanic and Atmospheric Administration/Geophysical Fluid Dynamics Laboratory, \\ Princeton, NJ 08540, USA \\ ${ }^{9}$ Geophysical Institute, University of Bergen and Bjerknes Centre for Climate Research, 5007 Bergen, Norway \\ ${ }^{10}$ Max Planck Institute for Meteorology, Bundesstr. 53, 20146 Hamburg, Germany \\ ${ }^{11}$ Uni Research Climate, Bergen, Norway \\ ${ }^{12}$ Bjerknes Centre for Climate Research, Bergen, Norway
}

Correspondence to: M. Gehlen (marion.gehlen@1sce.ipsl.fr)

Received: 6 May 2014 - Published in Biogeosciences Discuss.: 11 June 2014

Revised: 28 October 2014 - Accepted: 3 November 2014 - Published: 11 December 2014

\begin{abstract}
This study aims to evaluate the potential for impacts of ocean acidification on North Atlantic deep-sea ecosystems in response to IPCC AR5 Representative Concentration Pathways (RCPs). Deep-sea biota is likely highly vulnerable to changes in seawater chemistry and sensitive to moderate excursions in $\mathrm{pH}$. Here we show, from seven fully coupled Earth system models, that for three out of four RCPs over $17 \%$ of the seafloor area below $500 \mathrm{~m}$ depth in the North Atlantic sector will experience $\mathrm{pH}$ reductions exceeding -0.2 units by 2100 . Increased stratification in response to climate change partially alleviates the impact of ocean acidification on deep benthic environments. We report on major $\mathrm{pH}$ reductions over the deep North Atlantic seafloor (depth $>500 \mathrm{~m}$ ) and at important deep-sea features, such as seamounts and canyons. By 2100, and under the high $\mathrm{CO}_{2}$ scenario RCP8.5, pH reductions exceeding $-0.2(-0.3)$ units
\end{abstract}

are projected in close to $23 \%(\sim 15 \%)$ of North Atlantic deep-sea canyons and $\sim 8 \%(3 \%)$ of seamounts - including seamounts proposed as sites of marine protected areas. The spatial pattern of impacts reflects the depth of the $\mathrm{pH}$ perturbation and does not scale linearly with atmospheric $\mathrm{CO}_{2}$ concentration. Impacts may cause negative changes of the same magnitude or exceeding the current target of $10 \%$ of preservation of marine biomes set by the convention on biological diversity, implying that ocean acidification may offset benefits from conservation/management strategies relying on the regulation of resource exploitation. 


\section{Introduction}

Global ocean anthropogenic carbon inventories suggest that the ocean took up a cumulative $\sim 155 \pm 31 \mathrm{PgC}\left(10^{15} \mathrm{~g}\right.$ of carbon) in 2010 (Khatiwala et al., 2013). This uptake of $\mathrm{CO}_{2}$ is causing profound changes in seawater chemistry resulting from increased hydrogen ion concentration (decrease in $\mathrm{pH}, \mathrm{pH}=-\log 10\left[\mathrm{H}^{+}\right]$), referred to as ocean acidification (IPCC, 2011). Experimental and modelling studies provide compelling evidence that ocean acidification will put marine ecosystems at risk (e.g. Orr et al., 2005; Kroeker et al., 2013). However, with the exception of assessments focusing on cold-water coral systems (Barry et al., 2005, 2013; Fleeger et al., 2006; Guinotte et al., 2006; Tittensor et al., 2010), quantifications of biological consequences of ocean acidification mostly targeted surface ocean or coastal environments (Kroeker et al., 2010).The aim of this study is to extend our understanding of broad scale impacts of ocean acidification from the existing shallow water studies to focus specifically on deep-sea ecosystems. The deep sea is under increasing anthropogenic pressure as technological advances allow for exploitation of formerly inaccessible regions (Clauss and Hoog, 2002). While waste disposal, fishing and, in the future, mineral extraction are well recognized as dominant human pressures (Ramirez-Llodra et al., 2011), expert assessments urge consideration of climate change and ocean acidification impacts in future ecosystem conservation/management strategies (Taranto et al., 2012; Billé et al., 2013).

While previous studies quantified changes in carbonate mineral saturation state as a measure for potential detrimental impacts on deep calcifying communities (Guinotte et al., 2005, 2006; Turley et al., 2007; Fautin et al., 2009), this model-based assessment uses $\mathrm{pH}$. The tight control of $\mathrm{pH}$ at the cellular scale is an important prerequisite of proper cell functioning, and mechanisms of $\mathrm{pH}$ control are ubiquitous across many taxa (Seibel and Walsh, 2003, and references therein). Deep-sea organisms might be particularly vulnerable to changes in seawater chemistry, at least in part owing to limitations on rate processes, caused by low temperature (Childress, 1995; Seibel and Walsh, 2001) and possibly food availability (Ramirez-Llodra, 2002), as well as the environmental stability of their habitat in the past (Barry et al., 2011; Seibel and Walsh, 2003). A recent review by Somero (2012) highlights the link between environmental stability and the capacity to acclimate to future changes in environmental variables such as $\mathrm{pH}$. According to this study, environmental stability might impair the potential for acclimation. This stands in sharp contrast to shallow water or intertidal organisms, which are adapted to a dynamic environment with large changes in temperature and seawater chemistry (Hofmann et al., 2011; Duarte et al., 2013).

A model sensitivity study by Gehlen et al. (2008) suggested the potential for large $\mathrm{pH}$ reductions (up to $-0.6 \mathrm{pH}$ units) in the deep North Atlantic. Regions of large $\mathrm{pH}$ reductions coincided with areas of deep-water formation. Deep- water formation drives the rapid propagation of surfacederived changes in carbonate chemistry to depth as underlined by high vertically integrated water column inventories of anthropogenic carbon (Sabine et al., 2004), as well as tritium and chlorofluorocarbon distributions (Doney and Jenkins, 1994). Gehlen et al. (2008) used output from a single model and for a scenario following an atmospheric $\mathrm{CO}_{2}$ increase of $1 \%$ per year over 140 years starting from an atmospheric $\mathrm{CO}_{2}$ level of $286 \mathrm{ppm}$. This rate of increase is about twice as large as the rate typical for a high-end IPCC concentration pathway. The study did not include circulation changes in response to climate change.

Here we extend the study by Gehlen et al. (2008) by analysing $\mathrm{pH}$ projections from seven Earth system models that contributed to the Coupled Model Intercomparison Project Phase 5 (CMIP5) and for four different Representative Concentration Pathways (RCPs; Van Vuuren et al., 2011) ranging from a strong emission mitigation scenario (RCP2.6) to the high- $\mathrm{CO}_{2}$ scenario RCP8.5. We assess the magnitude of deep-water $\mathrm{pH}$ reductions in the North Atlantic $\left(35-75^{\circ} \mathrm{N}\right.$, $0-90^{\circ} \mathrm{W}$ ) over this century in response to atmospheric $\mathrm{CO}_{2}$ increase and climate change. The North Atlantic is a wellventilated region of the world ocean and, despite a projected increase in stratification, will remain well oxygenated in the future (Bopp et al., 2013). The study complements assessments by Bopp et al. (2013) and Mora et al. (2013), which evaluated large-scale average $\mathrm{pH}$ reductions in response to the same RCP pathways, but without a detailed discussion of spatial patterns and their link to circulation. We define a critical threshold for $\mathrm{pH}$ reductions based on evidence from palaeo-oceanographic studies, contemporary observations and model results. Future multi-model projections of $\mathrm{pH}$ changes over the seafloor are analysed with reference to this threshold and without discrimination of particular habitats first. Next, model results are put into the perspective of ecosystem conservation by evaluating changes in $\mathrm{pH}$ against the distribution of seamounts and deep-sea canyons. These features are known as sites of high-biodiversity deep-sea ecosystems, such as cold-water corals and sponge communities (ICES, 2007; Clark et al., 2010; De Leo et al., 2010) and are selected as representative examples of deep-sea environments.

\section{Material and methods}

\subsection{Earth system models}

Our study draws on results from two types of Earth system models: (1) the Bern3-D-LPJ carbon-cycle/climate model (Steinacher et al., 2013; Roth and Joos, 2013) and (2) seven fully coupled three-dimensional atmosphere ocean climate models that participated in the Coupled Model Intercomparison Project Phase 5 (CMIP5; Taylor et al., 2011) and contributed to the Fifth Assessment Report of the Inter- 
governmental Panel on Climate Change (IPCC AR5). The Bern3-D-LPJ is a model of intermediate complexity featuring a 3-D geostrophic-balance ocean and 2-D atmospheric energy and moisture-balance model. The cycle of carbon and related tracers is represented including prognostic formulations for marine production, a seafloor sediment and a dynamic global vegetation model. This model is relatively costefficient compared to CMIP5 models. It is used to evaluate the order of magnitude of $\mathrm{pH}$ reductions associated with past abrupt climate change by analysing results from freshwater hosing experiments (Bryan, 1986; Marchal et al., 1999; Matsumoto and Yokoyama, 2013).

Concerning the subset of CMIP5 models, we selected models for which 3-D pH fields were available and that had been part of a published multi-model evaluation (Bopp et al., 2013). We analyse output for four future atmospheric CO2 concentration scenarios (Representative Concentration Pathways, RCPs), along with the corresponding pre-industrial control simulations, piControl. The nomenclature follows CMIP5 recommendations. Historical simulations cover the period between 1870 and 2005 and are followed by climate change scenarios according to RCP8.5, RCP6.0, RCP4.5 and RCP2.6 from 2006 to 2100 (Van Vuuren et al., 2011; Moss et al., 2010). RCP identifiers refer to the additional radiative forcing in 2100 relative to pre-industrial (or before 2100 in case of the peak-and-decline scenario RCP2.6). These additional radiative forcings correspond to atmospheric $\mathrm{CO}_{2}$ levels in 2100 of 421, 538, 670 and $936 \mathrm{ppm}$ for RCP2.6, RCP4.5, RCP6.0 and RCP8.5. Individual RCPs differ with respect to the temporal evolution of atmospheric $\mathrm{CO}_{2}$ and range from a stringent emission mitigation RCP2.6 to the high- $\mathrm{CO}_{2}$ scenario RCP8.5. The complete set of RCPs was not available for all models. Please refer to Table S1 (Supplement) for model name, scenario and references.

\subsection{Deep-sea ecosystems}

This study uses data sets of seamounts (Yesson et al., 2011) and canyons (Harris and Whiteway, 2011). For seamounts, these data include location, height and surface assuming a conical shape. For canyons, the data consist of a highresolution vector database of canyon centre lines that was converted into a raster data set of canyon presence (using ArcGIS v10) for analysis. Data were projected on a $1^{\circ} \times 1^{\circ}$ regular grid.

\subsection{Post-treatment of model output and data}

\subsubsection{Post-treatment of CMIP5 model output}

Model output is interpolated on a regular grid of $1^{\circ} \times 1^{\circ}$ resolution. Anomalies are computed as the difference between the decade 2090-2099 and the long-term mean of the preindustrial state. As the focus of this study is on impacts on benthic communities, we quantify $\mathrm{pH}$ changes in the deepest model box over a topography range from 500 to $>4500 \mathrm{~m}$ water depth.

\subsubsection{Computation of the area of seamounts for impact assessment}

The area of North Atlantic seafloor impacted by ocean acidification is estimated on the basis of individual grid cells for which the reduction in $\mathrm{pH}$ exceeded $\geq 0.2$ or 0.3 units. The impacted area follows as the integral of the area of these $1^{\circ} \times 1^{\circ}$ grid cells. The area of seamounts with a $\mathrm{pH}$ reduction $\geq 0.2$ or 0.3 units is computed based on distribution and height assuming a conical shape (Danovaro et al., 2008, Yesson et al., 2011). The database provides height above seafloor and base area. The area of the seamount $(A)$ is given by

$A=\pi r \sqrt{r^{2}+\left(h+h^{\prime}\right)^{2}}$,

where $r$ is the base radius of the seamount and $h+h^{\prime}$ is the height. The height impacted by a $\mathrm{pH}$ reduction exceeding the threshold $\left(h^{\prime}\right)$ is diagnosed from the depth of the $\mathrm{pH}$ anomaly corresponding to the threshold. The radius of the seamount at the depth of the anomaly $\left(r^{\prime}\right)$ is obtained from the Thales theorem:

$$
\begin{aligned}
& \frac{r^{\prime}}{r}=\frac{h^{\prime}}{h}, \\
& \text { as } r^{\prime}=\frac{h^{\prime}}{h} r .
\end{aligned}
$$

The final expression of $r^{\prime}$ is the positive analytical solution of the fourth-order polynomial

$$
\begin{aligned}
& \frac{A^{2}}{\pi^{2}}=\frac{h^{2}}{h^{\prime 2}} r^{\prime 2}\left(\frac{h^{2}}{h^{\prime 2}} r^{\prime 2}+\left(h+h^{\prime}\right)^{2}\right), \\
& \text { as } r^{\prime}= \pm \frac{h^{\prime}}{h}\left[\frac{1}{2}\left(-1 \pm \sqrt{\frac{4 A^{2}}{\pi^{2} h^{2}}}\right)\right]^{\frac{1}{2}} .
\end{aligned}
$$

The impacted area of the seamount $\left(A^{*}\right)$ follows from the depth of $\mathrm{pH}$ anomaly as a function of seamount height:

$$
\begin{aligned}
& A^{*}=\pi \frac{h^{\prime}}{h}\left[\frac{1}{2}\left(-1+\sqrt{\frac{4 A^{2}}{\pi^{2} h^{2}}}\right)\right]^{\frac{1}{2}} \\
& \left(h^{\prime 2}+\frac{h^{\prime}}{h^{2}}\left[\frac{1}{2}\left(-1+\sqrt{\frac{4 A^{2}}{\pi^{2} h^{2}}}\right)\right]\right),
\end{aligned}
$$

where $A$ is the total surface area of the seamount. 
a)

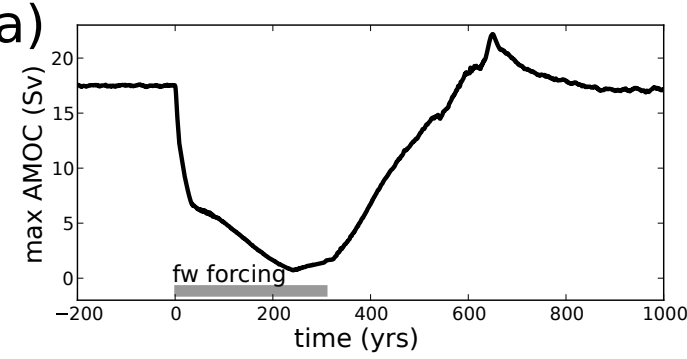

C)

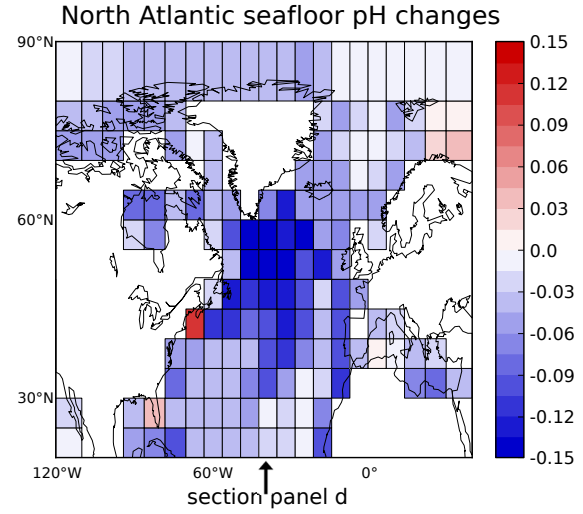

b)

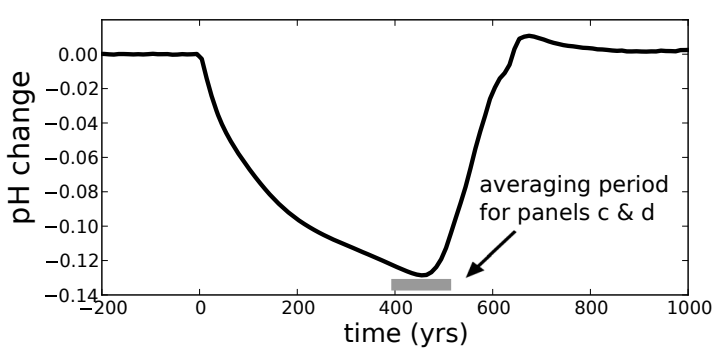

d) North Atlantic pH changes at $38.5^{\circ} \mathrm{W}$

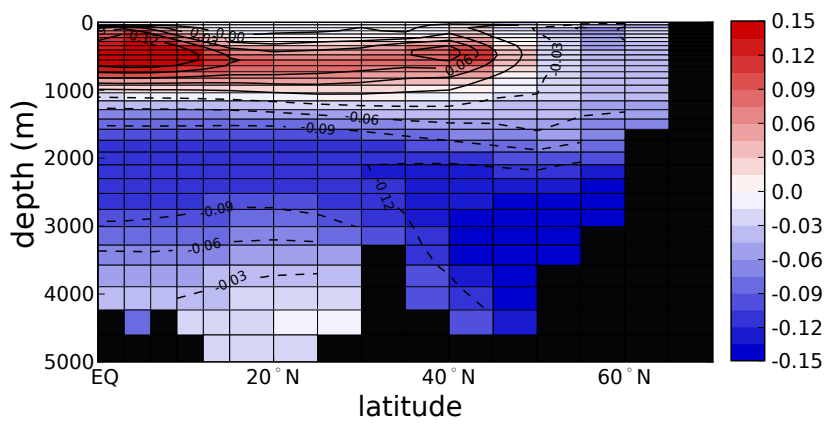

Figure 1. North Atlantic freshwater hosing experiment. (a) Time series of strength of Atlantic Meridional Overturning Circulation (Sv); freshwater release occurred over 300 years (grey bar). (b) Times series of $\mathrm{pH}$ change relative to pre-industrial averaged over the deep (below $2000 \mathrm{~m}$ ) North Atlantic $\left(45-65^{\circ} \mathrm{N}\right.$ ). (c) Spatial distribution of the $\mathrm{pH}$ reduction averaged over experiment years 400-450 (grey bar in panel b) in terms of $\mathrm{pH}$ anomalies relative to pre-industrial at the seafloor and (d) in a section through the Atlantic at $38.5^{\circ} \mathrm{W}$.

\section{Results and discussion}

\subsection{Environmental stability and critical threshold for $\mathrm{pH}$ reduction}

Considering that environmental stability might impair the potential for acclimation, we assessed $\mathrm{pH}$ changes over glacialinterglacial timescales and for past events of rapid climate changes recognized for having driven major reorganizations in North Atlantic circulation and carbonate chemistry.

The $\mathrm{pH}$ is defined as the negative logarithm of the hydrogen ion concentration $\left(\left[\mathrm{H}^{+}\right]\right)$. From the basic properties of logarithms it follows that the difference in $\mathrm{pH}$ equals the logarithm of the ratio of hydrogen ion concentrations. For a given $\mathrm{pH}$ change, the change in $\left[\mathrm{H}^{+}\right], \Delta\left[\mathrm{H}^{+}\right]$, is a linear function of the initial hydrogen ion concentration $\left(\left[\mathrm{H}^{+}\right]_{i}\right)$ as $\Delta\left[\mathrm{H}^{+}\right]=\left[\mathrm{H}^{+}\right]_{i}\left(\left(1 / 10^{\Delta \mathrm{pH}}\right)-1\right)$. Hence, the larger the initial $\left[\mathrm{H}^{+}\right]$, the larger the perturbation (Supplement Fig. S1). Contrasting shallow and deep environments highlights that absolute changes in $\left[\mathrm{H}^{+}\right]$are amplified at depth for any threshold, that is for environments of low natural variability.

\subsubsection{Glacial-interglacial timescales}

The palaeo-record permits evaluation of environmental variability of the deep ocean over the past million years. Avail- able evidence indicates a low variability over this time interval (Elderfield et al., 2012; Yu et al., 2010, 2013). Changes in carbonate chemistry were small in the deep ocean compared to surface layers (Yu et al., 2010). Recent studies re-evaluated deep-water $\mathrm{pH}$ changes between glacial and present (Sanyal et al., 1995), arguing that carbonate compensation kept deepwater pH close to constant (Hönisch et al., 2008). We use data available in Yu et al. (2010) (and associated supplement) and follow their reasoning to infer dissolved inorganic carbon (DIC) changes from $\left[\mathrm{CO}_{3}^{2-}\right]$ and hence alkalinity in order to compute associated changes in $\mathrm{pH}$ for sediment core BOFS $8 \mathrm{~K}\left(52.5^{\circ} \mathrm{N}, 22.1^{\circ} \mathrm{W}, 4045 \mathrm{~m}\right)$. This $\mathrm{pH}$ change is computed using $\mathrm{CO}_{2}$ sys (http://cdiac.ornl.gov/ oceans/co2rprt.html) with alkalinity and DIC as input variables, along with temperature, depth, phosphate and silicate (Yu et al., 2010). We estimate a $\mathrm{pH}$ reduction of $\sim 0.1 \mathrm{pH}$ units for North Atlantic deep water over the early deglacial (17500 to 14500 years before present).

\subsubsection{Rapid events associated with freshwater release: Heinrich and Dansgaard Oeschger events}

Model experiments yield maximum $\mathrm{pH}$ reductions in North Atlantic deep water below $0.15 \mathrm{pH}$ units in response to a shutdown of the North Atlantic Meridional Overturning Circulation (AMOC, Fig. 1). To realize an abrupt shutdown of 
the AMOC, different durations of freshwater perturbations in the North Atlantic on top of a pre-industrial steady state have been tested releasing a total of $3 \times 10^{15} \mathrm{~m}^{3}$ freshwater $(\sim 9 \mathrm{~m}$ sea level equivalent). In terms of $\mathrm{pH}$ changes in the North Atlantic region, the experiment with a 300-year freshwater forcing of $0.33 \mathrm{~Sv}$ results in the strongest response (Fig. 1a). In these experiments, the cause of the $\mathrm{pH}$ decrease is not high atmospheric $\mathrm{CO}_{2}\left(\mathrm{CO}_{2}\right.$ only increases a few ppm during the freshwater experiment), but is mainly a result of the decrease in deep-ocean ventilation. This leads to the additional accumulation of DIC by the respiration of organic matter. Although alkalinity is also increased in the deep by the dissolution of carbonate particles settling through the water column, it does not compensate for the increase in DIC leading to more acidic waters in the deep. The most extreme negative excursion of the $\mathrm{pH}$ averaged over the deep (below $2000 \mathrm{~m}$ ) North Atlantic $\left(45-65^{\circ} \mathrm{N}\right)$ occurs $\sim 150$ years after the end of the freshwater forcing with a decrease of $\sim 0.13 \mathrm{pH}$ units relative to the unperturbed pre-industrial state (Fig. 1b). The $\mathrm{pH}$ decrease does not exceed $-0.18 \mathrm{pH}$ units in any of the individual grid boxes. In Fig. 1c and d the spatial distribution of the $\mathrm{pH}$-reduction averaged over years 400-450 (i.e. during the maximum of the $\mathrm{pH}$ decrease) is shown in terms of $\mathrm{pH}$ anomalies at the seafloor and in a section through the Atlantic at $38.5^{\circ} \mathrm{W}$.

\subsubsection{Critical threshold for $\mathrm{pH}$ reductions}

For the purpose of evaluating the potential for negative impacts on deep-sea benthic environments, a critical threshold for $\mathrm{pH}$ reduction needs to be identified. Reductions of $\mathrm{pH}$ exceeding the envelope set by past and present natural variability are considered as critical. Palaeo-evidence suggests that the deep-sea fauna has evolved under conditions of environmental variability confined to a narrow range over the past million years (Yu et al., 2010; Elderfield et al., 2012). Many past episodes of climate change occurred over significantly longer timescales than the current anthropogenic perturbation of the climate system, allowing carbonate compensation to keep deep-water $\mathrm{pH}$ close to constant (Hönisch et al., 2008). This is corroborated by computing $\mathrm{pH}$ reduction over glacial-interglacial cycles for a North Atlantic site. Decadal-to-centennial changes are addressed by freshwater hosing model experiments to simulate effects of circulation changes associated with rapid Heinrich and Dansgaard Oeschger events. In both cases, $\mathrm{pH}$ reductions are below $0.15 \mathrm{pH}$ units. Similarly, small amplitude natural temporal $\mathrm{pH}$ variability at depth emerges from a multi-annual time series station (González-Dávila et al., 2010) and the analysis of the long pre-industrial simulation "piControl" (Fig. S2). In summary, natural $\mathrm{pH}$ variations on multi-annual, decadalto-century, and longer timescales were likely smaller than $0.2 \mathrm{pH}$ units on the regional-to-basin scale in the deep Atlantic and at least for the past million years.
This suggests that $\mathrm{pH}$ variations of up to 0.1 to $0.2 \mathrm{pH}$ units do not present a risk for marine life.

This leads us to define two thresholds for $\mathrm{pH}$ reduction between pre-industrial and the end of the 21 st century: -0.2 and $-0.3 \mathrm{pH}$ units. Both stand for $\mathrm{pH}$ reductions exceeding palaeo-record-based estimates of changes in North Atlantic deep-water chemistry over the past 10000 years, as well as being much larger than the amplitude of natural temporal variability of $\mathrm{pH}$ in the deep North Atlantic (GonzálezDávila et al., 2010). The first threshold (-0.2) is in line with recommendations by environmental agencies (Schubert et al., 2006) following the precautionary principle, and is reported to increase mortality of deep-sea benthic organisms during in situ exposure experiments (Barry et al., 2005). The second threshold $(-0.3)$ allows for bracketing of a range of changes spanning from an $\sim 58 \%$ increase in hydrogen ion concentration up to $\sim 100 \%$.

\subsection{Projections of $\mathrm{pH}$ reductions over the 21st century}

Time series of atmospheric $\mathrm{CO}_{2}(\mathrm{ppm})$ for three out of four IPCC RCP scenarios between 2006 and 2100 show an increase in $\mathrm{CO}_{2}$ over this century; only RCP2.6 does not show a general increase with time (Fig. 2a). The corresponding simulated $\mathrm{pH}$ reductions for surface and deep North Atlantic waters are presented in Fig. $2 \mathrm{~b}$ and c. Projected $\mathrm{pH}$ changes are indicated as the multi-model mean along with the between-model spread. Monitoring at time series stations reveals that the observed surface ocean $\mathrm{pH}$ decrease tracks increasing atmospheric $p \mathrm{CO}_{2}$ (Orr, 2011). This trend is confirmed by the decline in simulated surface ocean $\mathrm{pH}$ (Fig. 2b) with a small between-model spread. In the surface ocean the extent of ocean acidification is set by the atmospheric $\mathrm{CO}_{2}$ trajectory, along with physical climate change, namely warming and associated changes in ocean circulation and $\mathrm{CO}_{2}$ thermodynamic properties. Surface waters, with high levels of dissolved anthropogenic $\mathrm{CO}_{2}$ and characterized by low $\mathrm{pH}$ values, are entrained to the interior ocean during seasonal mixed layer deepening and deep convection episodes. As a result, deep $\mathrm{pH}$ changes (Fig. 2c) reflect atmospheric $\mathrm{CO}_{2}$ to a lesser extent. Because the deep-water formation differs between models, the inter-model spread is significantly larger in deep waters than for the surface ocean.

The spatial pattern of $\mathrm{pH}$ reductions is exemplified for RCP4.5 and RCP8.5 in Fig. 3 (Fig. S3 for RCP2.6 and RCP6.0). Under RCP4.5 (Fig. 3a) and RCP8.5 (Fig. 3b), pH reductions crossing the -0.2 threshold are projected for continental slopes and a latitudinal band extending from 55 to $65^{\circ} \mathrm{N}$. Since the $\mathrm{pH}$ perturbation originates at the sea surface, the continental slope and topographic heights (e.g. midAtlantic ridge) experience the largest $\mathrm{pH}$ reductions. Increasing impact on the sea floor between RCP4.5 and RCP8.5 for a threshold of -0.2 reflects the depth exposure to the $\mathrm{pH}$ perturbation of continental slopes and the mid-Atlantic ridge. In summary, the spatial pattern is set by a combination of 

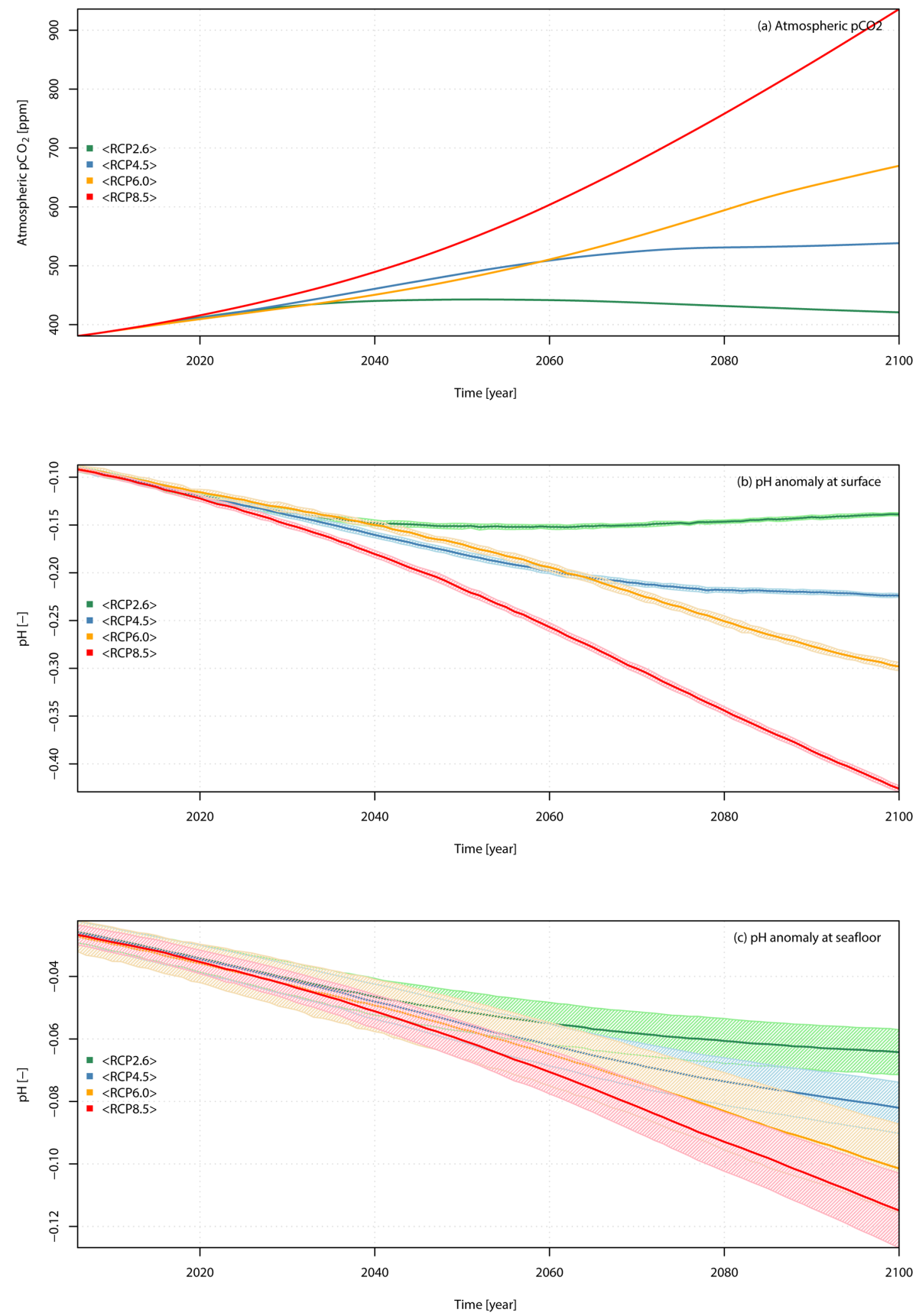

Figure 2. Time series of (a) atmospheric $\mathrm{CO}_{2}$ (ppm) for RCP2.6, RCP4.5, RCP6.0 and RCP8.5 scenarios between 2006 and 2100 and corresponding simulated average North Atlantic $\mathrm{pH}$ changes relative to the pre-industrial mean for (b) surface waters and (c) deep waters. Hatching indicates the $2.5-97.5 \%$ confidence interval of multi-model averages.

topography and North Atlantic circulation pathways. It reflects the transfer of the surface born anomaly of $\mathrm{pH}$ to the ocean interior during deep-water formation and downstream transport away from convection sites by the deep western boundary current.

By the end of the 21st century, projected $\mathrm{pH}$ reductions (Table 1) cross the -0.2 threshold for all scenarios except RCP2.6. For RCP2.6, deep-water $\mathrm{pH}$ reductions remain be- low thresholds with likely limited impact on benthic environments. Under moderate RCP4.5, a decrease in $\mathrm{pH}$ beyond -0.2 units is projected for large areas of the North Atlantic, with about $16.7 \pm 4.2 \%$ of the sea floor area below $500 \mathrm{~m}$ being impacted. This estimate increases to $21.0 \pm 4.4 \%$ of the North Atlantic sea floor area under the most severe scenario (RCP8.5) and is still $14.0 \pm 3.3 \%$ of the sea floor for a threshold of -0.3 . The area impacted does not scale linearly 
Table 1. Fraction of North Atlantic seafloor $\left(35-75^{\circ} \mathrm{N}, 0-90^{\circ} \mathrm{W}\right)$ below $500 \mathrm{~m}$ experiencing a reduction in $\mathrm{pH} \geq 0.2$, as well as $\geq 0.3$, at the end of the 21 st century. Fractions for multi-model mean and standard deviation are given in percentage of impacted surface area relative to the total surface seafloor area of the North Atlantic sector. $n$ is the number of simulations available at time of analysis for each RCP.

\begin{tabular}{lrrr|rr}
\hline & $n$ & $\mathrm{pH}$ reduction $\geq 0.2$ & \multicolumn{2}{c}{$\mathrm{pH}$ reduction $\geq 0.3$} \\
\cline { 2 - 6 } & & mean $(\%)$ & $\mathrm{SD}(\%)$ & mean $(\%)$ & $\mathrm{SD}(\%)$ \\
\hline RCP2.6 & 6 & 1.2 & 1.1 & 0.0 & 0.1 \\
RCP4.5 & 7 & 16.7 & 4.2 & 0.6 & 0.5 \\
RCP4.5/fixclim & 2 & 18.1 & n.a & 0.8 & n.a \\
RCP6.0 & 4 & 19.9 & 5.0 & 4.4 & 1.5 \\
RCP8.5 & 7 & 21.0 & 4.4 & 14.0 & 3.3 \\
\hline
\end{tabular}

with atmospheric $\mathrm{CO}_{2}$ (Table 1) but levels off at higher RCPs for the -0.2 threshold. The $-0.3 \mathrm{pH}$ unit threshold (a $100 \%$ increase in $\left[\mathrm{H}^{+}\right]$) is not reached for RCP4.5, and only modest impacts are projected for RCP6.0 (Table 1). We expect, however, an increase in impacted area for all scenarios and $\mathrm{pH}$ thresholds beyond 2100 in response to legacy effects of $\mathrm{CO}_{2}$ emissions and ongoing downward propagation of the pH perturbation (Frölicher and Joos, 2010).

\subsubsection{Opposing effects of climate change and ocean acidification}

The progression from RCP2.6 to RCP8.5 corresponds to a series of increasing geochemical (atmospheric $p \mathrm{CO}_{2}$ ) and physical (climate change, defined here as changes in ocean dynamics in response to atmospheric warming) forcing with opposing effects on deep-ocean acidification.

In order to distinguish between the physical and geochemical drivers of North Atlantic deep-water acidification, we assessed two contrasting simulations available for two Earth system models (GFDL-ESM2M and IPSL-CM5ALR) for RCP4.5. The first simulation (Fig. 4a) includes climate change effects on ocean circulation and geochemical effects on the seawater $\mathrm{CO}_{2}$ system in response to atmospheric $p \mathrm{CO}_{2}$ increase (RCP4.5). In the second experiment (Fig. 4b), the circulation and ocean physics are kept at pre-industrial conditions, but atmospheric $\mathrm{CO}_{2}$ levels following RCP4.5 are used to force ocean acidification (RCP4.5/fixclim). The difference in $\mathrm{pH}$ between RCP4.5 and RCP4.5/fixclim (Fig. 4c) allows, at first order and within the limits of non-linearities (Schwinger et al., 2014), for isolation of the effect of climate change on $\mathrm{pH}$ changes. The negative differences in $\mathrm{pH}$ on panel $\mathrm{c}$ indicate stronger acidification in RCP4.5/fixclim, and suggest a slight alleviation of ocean acidification at depth and over the timescale of this study by climate change. In the experiment where ocean circulation was held at pre-industrial conditions (RCP4.5/fixclim), there was a small increase in the area impacted by $\mathrm{pH}$ re- ductions for all thresholds (Table 1). Largest differences in projected $\mathrm{pH}$ values between RCP4.5 and RCP4.5/fixclim co-occur with large negative anomalies in winter mixed layer depth maxima in the Labrador Sea and negative $\mathrm{pH}$ anomalies downstream of convection sites following the deep western boundary current (Doney and Jenkins, 1994). This is in line with the projected enhancement of stratification across the North Atlantic in response to increasing temperatures and freshening. It will result in changes in winter mixed layer depth and deep convection and a decrease in the Atlantic Meridional Overturning Circulation (Meehl et al., 2007; Cheng et al., 2013). While increasing atmospheric $\mathrm{CO}_{2}$ reduces $\mathrm{pH}$, increasing climate change reduces surfaceto-deep water exchange. In addition, topography modulates the extent of deep-water acidification. The combination of climate change, the non-linearities of the carbonate system, and topography explains the levelling-off of impacts in Table 1 for $\mathrm{pH}$ reductions exceeding -0.2 .

\subsubsection{Projected impacts on ecosystems}

In order to evaluate the risk for specific benthic ecosystems to be affected by $\mathrm{pH}$ reductions, we co-located seamounts (Fig. 3, black dots) and deep-sea canyons (Fig. 3, red dots) - both of which are key habitats of high biodiversity - and $\mathrm{pH}$ changes for RCP4.5 and RCP8.5 separately computed from the multi-model mean (see Supplement for RCP2.6 and RCP6.0). To further the evaluation of potential impacts of $\mathrm{pH}$ reductions beyond $\mathrm{pH}$ thresholds, we computed the area of seamounts for which a corresponding decrease is projected. A significant proportion of these habitats will be impacted by $\mathrm{pH}$ reductions exceeding -0.2 units by the end of the 21 st century under moderate to high emission scenarios (Fig. 5). The geographic pattern results in close to $22.5 \pm 5.3 \%(14.7 \pm 4.1 \%)$ of North Atlantic deep-sea canyons and $7.7 \pm 3.6 \%(2.7 \pm 0.9 \%)$ of seamount ecosystems being exposed to $\mathrm{pH}$ reductions exceeding $-0.2(-0.3)$ units under RCP8.5. Under the moderate scenario, RCP4.5, model projections indicate that $19.0 \pm 5.7 \%$ of deep-sea canyons and $3.5 \pm 1.6 \%$ of seamounts still will experience $\mathrm{pH}$ reductions exceeding the -0.2 threshold. The close to constant impact reflects the use of a diagnostic that is based on counts of features being impacted, in addition to the depth distribution and propagation of the $\mathrm{pH}$ anomaly.

Seamounts and deep-sea canyons are known as hotspots of biodiversity and harbour a variety of distinct communities including reef-building cold-water corals, soft coral gardens and deep-sea sponge aggregations (Buhl-Mortensen et al., 2010, 2012; Clark et al., 2010; De Leo et al., 2010; ICES, 2007). Recent assessments reveal a high level of anthropogenic pressures on these ecosystems (Clark et al., 2010; Ramirez-Llodra et al., 2011). While fishing and resource extraction are recognized as the dominant human pressures at present and in the near future, expert assessments highlight the need for an appropriate quantification 

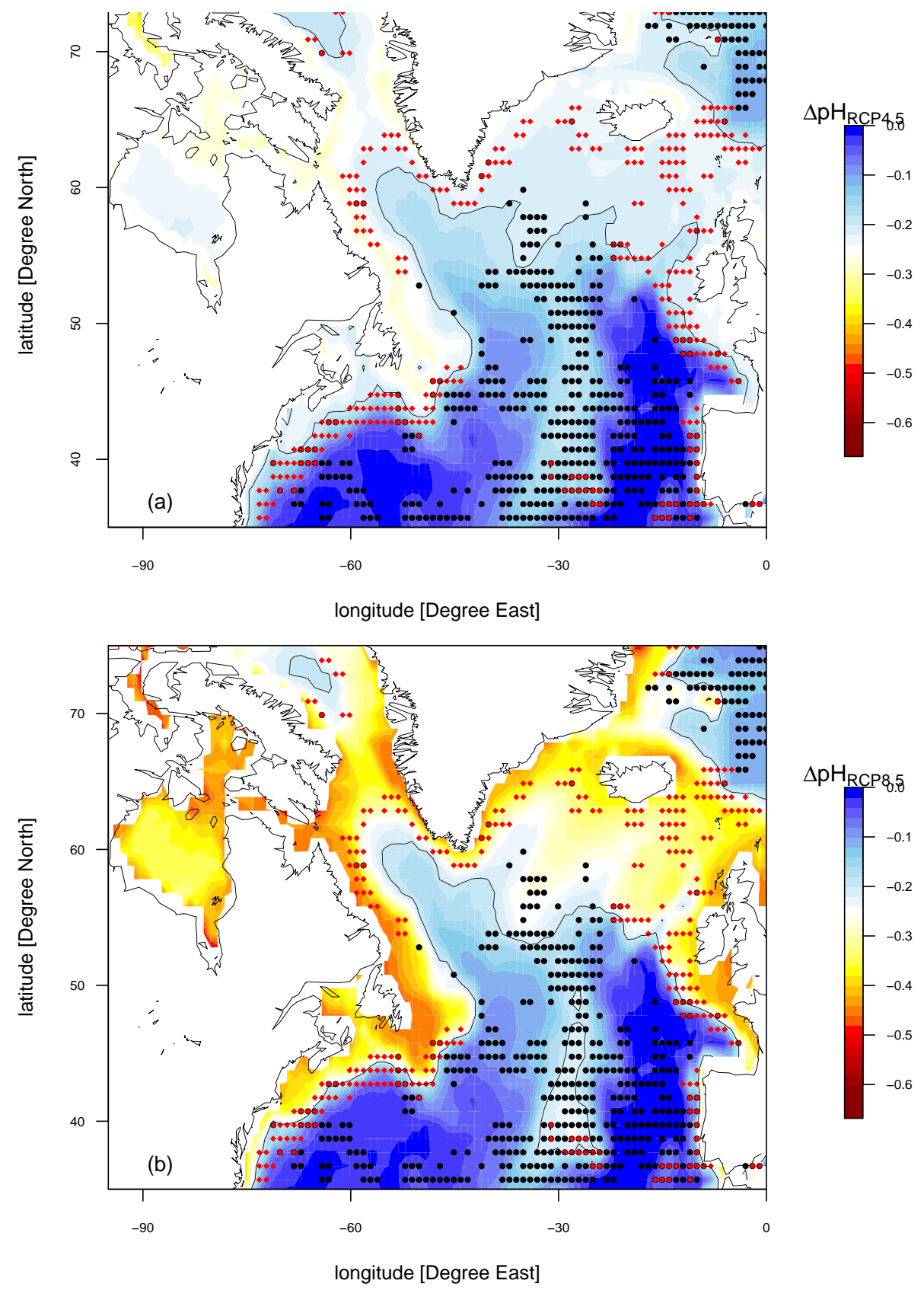

Figure 3. Projected changes in $\mathrm{pH}$ between pre-industrial and the experiments forced by IPCC RCP scenarios by 2100 . The panels show ensemble-mean differences in $\mathrm{pH}$ between the pre-industrial and the 2090-2100 average for (a) RCP4.5 and (b) RCP8.5. Locations of deepsea canyons and seamounts are indicated by red and black symbols, respectively. The $-0.2 \mathrm{pH}$ contour line is plotted to delineate areas experiencing $\mathrm{pH}$ reductions beyond this threshold.

of the impacts of climate change and ocean acidification (Taranto et al., 2012). Present international conservation targets aim at preserving $10 \%$ of marine biomes by 2020 (Convention of Biodiversity, 2011). Although not directly comparable to the outcome of model projections, it is nevertheless of interest to confront this preservation target with model results suggesting that $\sim 8 \%$ of North Atlantic seamounts and $23 \%$ of canyons will experience a decrease in $\mathrm{pH}$ ex- ceeding $0.2 \mathrm{pH}$ units by the year 2100 for the most severe scenario. Seamounts identified as marine protection areas in the OSPAR region and excluding active venting sites (e.g. Josephine Seamount, $36^{\circ} 40.02^{\prime} \mathrm{N}, 14^{\circ} 15.00^{\prime} \mathrm{W}$; Sedlo seamount, $40^{\circ} 12.8^{\prime} \mathrm{N}, 26^{\circ} 15.8^{\prime} \mathrm{W}$ ) fall within the area for which these $\mathrm{pH}$ reductions are projected.

Our knowledge of the ecology of deep benthic communities is still limited, and impacts of $\mathrm{pH}$ changes on these 

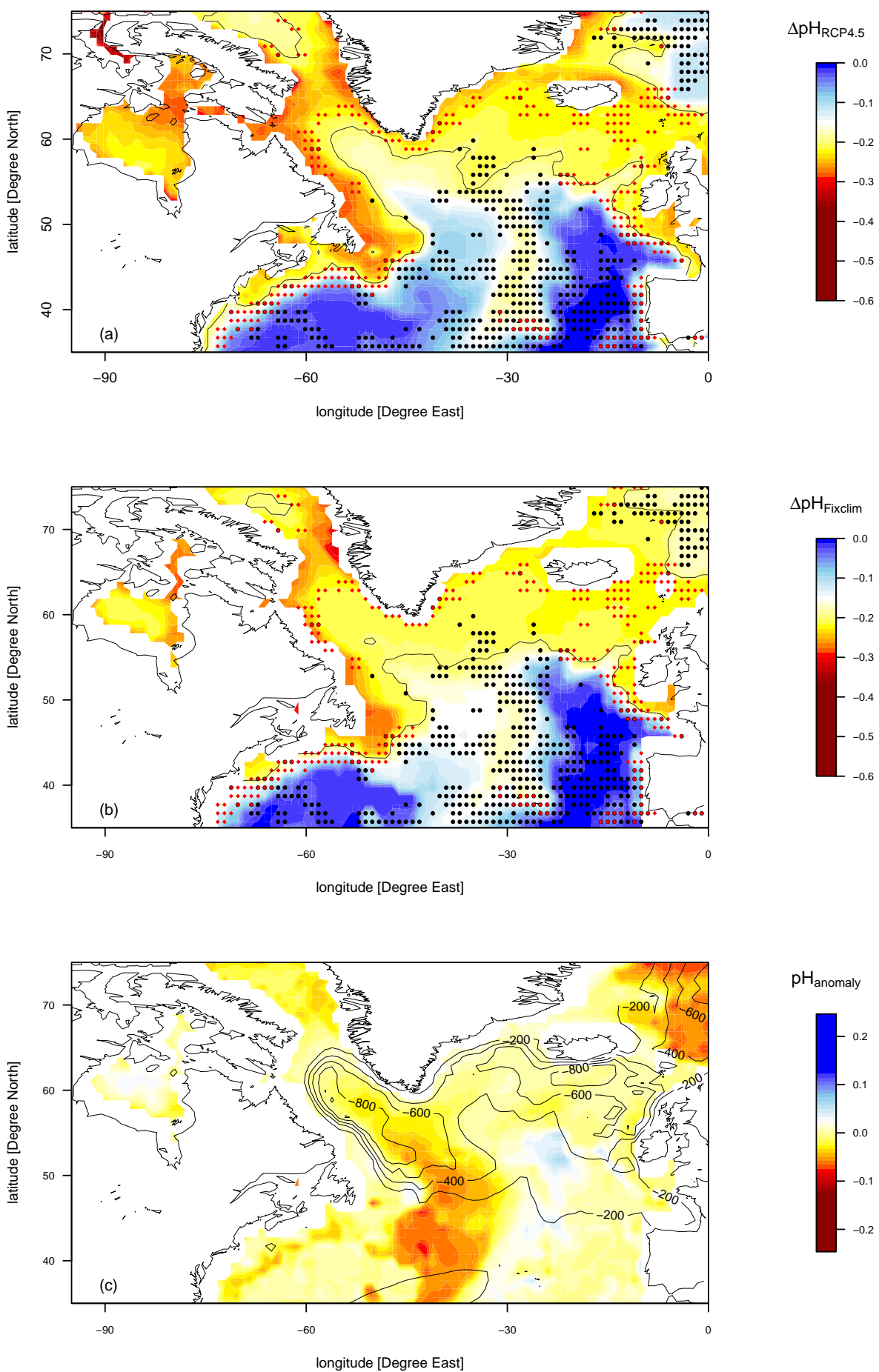

$\mathrm{pH}_{\text {anomaly }}$

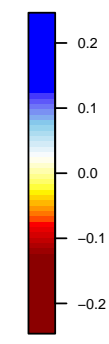

Figure 4. Projected changes in deep-ocean pH between pre-industrial and experiments forced with RCP scenarios by 2100: (a) RCP4.5, (b) $\mathrm{RCP} 4.5 /$ fixclim, and (c) difference in $\mathrm{pH}$ between (a) and (b) together with changes in maximum winter mixed layer depth (contour lines). The change in $\mathrm{pH}$ is computed as the difference in mean $\mathrm{pH}$ between the pre-industrial and the 2090-2100 average.

communities are difficult to evaluate owing to the lack of experimental and observational data. Rapid changes in $\mathrm{pH}$ will likely lead to disruption of extracellular acid-base balance, impedance of calcification and other physiological effects in deep-water organisms, and whatever acclimation is required may have increased energetic costs (Widdicombe and Spicer, $2008)$ - e.g. for metabolism/maintenance, growth, reproduction - and could extend to increases in mortality of both 

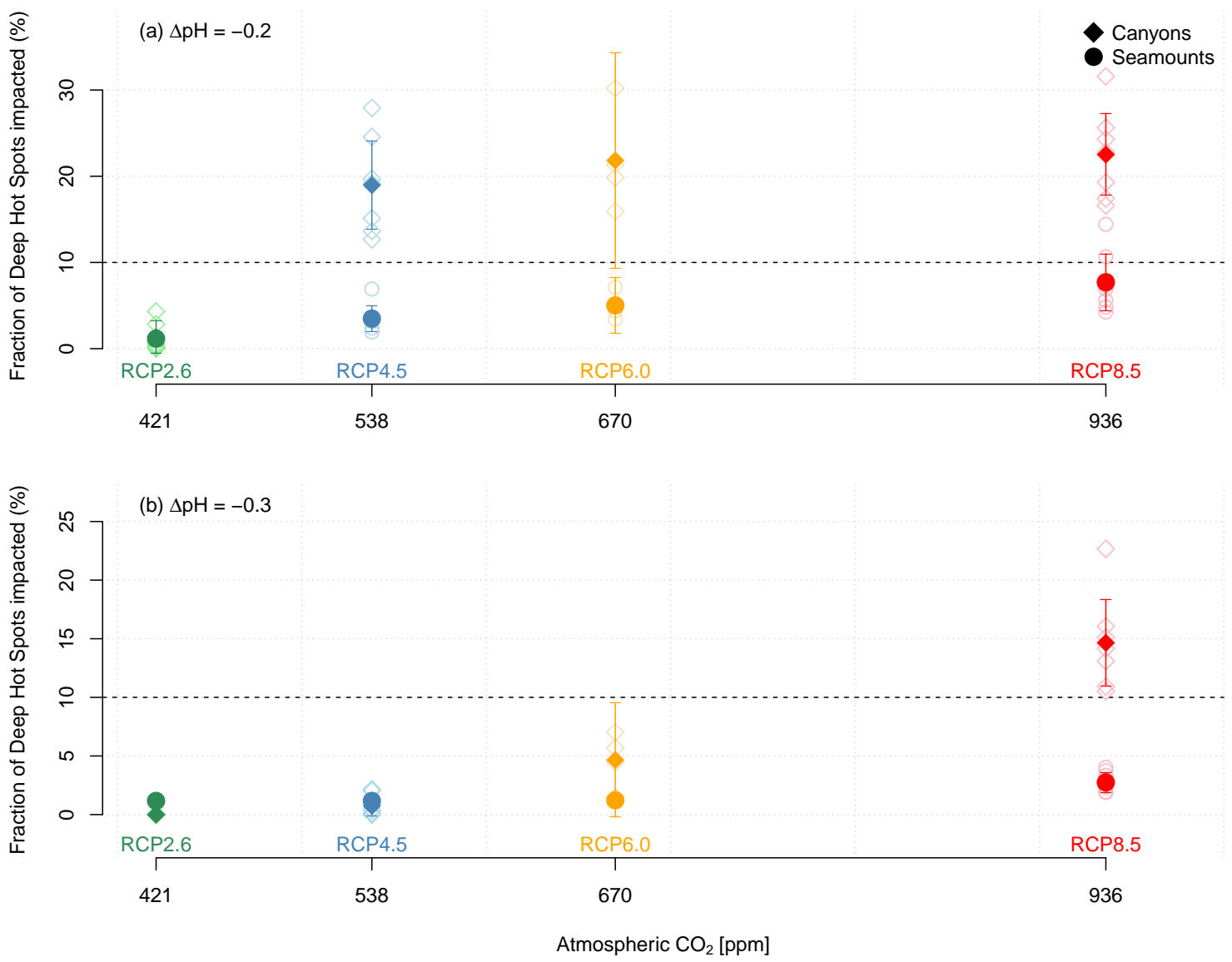

Figure 5. Projected impacts on seamounts (circles) and canyons (diamonds) as a function of atmospheric $\mathrm{CO}_{2}$ levels by year 2100 for $\mathrm{pH}$ reductions exceeding (a) -0.2 and (b) -0.3 . Impact is computed as the fraction of the surface area affected by a reduction exceeding the threshold for seamounts, as well as the number of canyons surrounded by waters for which the reduction in pH exceeding the threshold is projected. Model pH is the decadal mean (2090-2100). Note that the seamount and canyon multi-model averages for the RCP2.6 scenario overlie each other. Light coloured circles: values obtained for each Earth system model; dark coloured circles: multi-model average for each scenario. Vertical and horizontal bars: $2.5-97.5 \%$ confidence interval of multi-model averages.

adults and juveniles. Changes at the individual and population level will inevitably lead to more widespread ecosystem and community level changes and potential shifts in biodiversity (Hendriks et al., 2010) and ecosystem functioning (Danovaro et al., 2008). Biodiversity reductions could arise from a loss of species, or even functional or taxonomic groups, sensitive to $\mathrm{pH}$ change. The ecological implications of $\mathrm{pH}$ change could be more severe if keystone or habitat-forming species are impacted (Widdicombe and Spicer, 2008), which seems likely (Guinotte et al., 2006). These effects may be likely exacerbated in the presence of other stressors (Walther et al., 2009), such as global warming and projected reductions in deep-sea food supply (Bopp et al., 2013), as well as elevated resource exploitation and pollution. In particular, reductions in food supply to deep benthic communities are projected to result in a decrease in biomass and a shift towards smaller sized organisms (Jones et al., 2014). These changes will modify energy transfer rates through benthic food webs and may leave communities more susceptible to $\mathrm{pH}$ reductions. We propose these and future model projections be taken into account when defining longterm preservation and management approaches to deep-sea ecosystems.

\section{Conclusions}

This study assesses the potential for detrimental $\mathrm{pH}$ reduction to occur across the deep North Atlantic by the end of the 21 st century. It evaluates results from seven fully coupled Earth system models and for four Representative Concentration Pathways ranging from RCP2.6 to RCP8.5. In three out of the four scenarios, the multi-model analysis suggests that by 2100 over $17 \%$ of the seafloor area below $500 \mathrm{~m}$ depth in the North Atlantic sector will experience $\mathrm{pH}$ reductions exceeding -0.2 units. Enhanced stratification in response to warming and freshening of surface waters slightly counteracts deep-water acidification. $\mathrm{pH}$ reductions co-occur 
with sites of high deep-sea biodiversity such as seamounts and canyons. Model projections indicate that by the end of this century and for the high $\mathrm{CO}_{2}$ scenario RCP8.5, close to $23 \%(\sim 15 \%)$ of North Atlantic deep-sea canyons and $\sim 8 \%$ $(3 \%)$ of seamounts will experience $\mathrm{pH}$ reductions exceeding $-0.2(-0.3)$ units. Seamounts proposed as sites of marine protected areas are potentially threatened by these $\mathrm{pH}$ reductions. The spatial pattern of impacts reflects the depth of the $\mathrm{pH}$ perturbation and does not scale linearly with atmospheric $\mathrm{CO}_{2}$ concentration. Impacts may cause negative changes of the same magnitude or exceeding the current biodiversity target of $10 \%$ of preservation of marine biomes, implying that ocean acidification may offset benefits from conservation/management strategies relying on the regulation of resource exploitation.

\section{The Supplement related to this article is available online at doi:10.5194/bg-11-6955-2014-supplement.}

Acknowledgements. This work was supported through EU FP7 projects EPOCA (grant no. 211384) and CARBOCHANGE (grant no. 264879). D. O. B. Jones was funded by the UK Natural Environment Research Council as part of the Marine Environmental Mapping Programme (MAREMAP). S. C. Doney acknowledges support from the National Science Foundation (AGS-1048827). F. Joos acknowledges support from the Swiss National Science Foundation. This is a contribution from the BIOFEEDBACK project of the Centre for Climate Dynamics at Bjerknes Centre. C. Heinze and J. Tjiputra are grateful for support through NOTUR projects NN2980K and NN2345K as well as NorStore projects NS2980K and NS2345K for HPC CPU time and data storage. To analyse the CMIP5 data, this study benefited from the IPSL Prodiguer-Ciclad facility, which is supported by CNRS and UPMC, as well as Labex L-IPSL, which is funded by the ANR (grant no. ANR-10-LABX-0018) and by the European FP7 IS-ENES2 project (grant no. 312979).

Edited by: G. Herndl

\section{References}

Barry, J. P., Buck, K. R., Lovera, C., Kuhnz, L., and Whaling, P. J.: Utility of deep sea $\mathrm{CO}_{2}$ release experiments in understanding the biology of a high- $\mathrm{CO}_{2}$ ocean: Effects of hypercapnia on deep sea meiofauna, J. Geophys. Res., 110, C09S12, doi:10.1029/2004JC002629, 2005.

Barry, J. P., Widdicombe, S., and Hall-Spencer, J. M.: Effects of ocean acidification on marine biodiversity and ecosystem function, in: Ocean Acidification, edited by: Gattuso, J.-P. and Hansson, L., Oxford University Press, 192-209, 2011.

Barry, J. P., Buck, K. R., Lovera, C., Brewer, P. G., Seibel, B. A., Drazen, J. C., Tamburri, M. N., Whaling, P. J., Kuhnz, L., and
Pane, E. F.: The response of abyssal organisms to low $\mathrm{pH}$ conditions during a series of $\mathrm{CO}_{2}$-release experiments simulating deep-sea carbon sequestration, Deep-Sea Res. Pt. II, 92, 249260, 2013.

Billé, R., Kelly, R., Biastoch, A., Harrould-Kolieb, E., Herr, D., Joos, F., Kroeker, K., Laffoley, D., Oschlies, A., and Gattuso, J.-P.: Taking action against ocean acidification: A review of management and policy options, Environ, Manag, 52, 761-779, 2013.

Bopp, L., Resplandy, L., Orr, J. C., Doney, S. C., Dunne, J. P., Gehlen, M., Halloran, P., Heinze, C., Ilyina, T., Séférian, R., Tjiputra, J., and Vichi, M.: Multiple stressors of ocean ecosystems in the 21st century: projections with CMIP5 models, Biogeosciences, 10, 6225-6245, doi:10.5194/bg-10-6225-2013, 2013.

Bryan, F.: High-latitude salinity effects and interhemispheric thermohaline circulations, Nature, 323, 301-304, 1986.

Buhl-Mortensen, L., Vanreusel, A., Gooday, A. J., Levin, L. A., Priede, I. G., Buhl-Mortensen, P., Gheerardyn, H., King, N.J., and Raes, M.: Biological structures as a source of habitat heterogeneity and biodiversity on the deep ocean margins, Mar. Ecol., 31, 21-50, 2010.

Buhl-Mortensen, L., Buhl-Mortensen, P., Dolan, M. F. J., Dannheim, J., Bellec, V., and Holte, B.: Habitat complexity and bottom fauna composition at different scales on the continental shelf and slope of northern Norway, Hydrobiologia, 685, 191219, 2012.

Cheng, W., Chiang, J., and Zhang, D.: Atlantic Meridional Overturning Circulation (AMOC) in CMIP5 models: RCP and Historical Simulations, J. Climate, 26, 7187-7197, 2013.

Childress, J. J.: Are there physiological and biochemical adaptations of metabolism in deep-sea animals, Trends Ecol. Evol., 10, 1-36, 1995.

Clark, M. R., Rowden, A. A., Schlacher, T., Williams, A., Consalvey, M., Stocks, K. I., Rogers, A. D., O'Hara, T. D., White, M., Shank, T. M., and Hall-Spencer, J. M.: The ecology of seamounts: structure, function, and human impacts, Annu. Rev. Mar. Sci., 2, 253-278, 2010.

Clauss, G. and Hoog, S.: Deep Sea Challenges of Marine Technology and Oceanographic Engineering, Developments in Marine Technology 12, Science-Technology Synergy for Research in the Marine Environment: Challenges for the XXI Century, Elsevier, Oxford, England, 2002.

Convention on Biodiversity (CBD): target 11, document COP/10/INF/12/Rev.1, http://www.cbd.int/sp/targets/rationale/ target-11/, 2011.

Danovaro, R., Gambi, C., Dell'Anno, A., Corinaldesi, C., Fraschetti, S., Vanreusel, A., Vincx, M., and Gooday, A. J.: Exponential decline of deep-sea ecosystem functioning linked to benthic biodiversity loss, Curr. Biol., 18, 1-8, 2008.

De Leo, F. C., Smith, C. R., Rowden, A. A., Bowden, D. A., and Clark, M. R.: Submarine canyons: hotspots of benthic biomass and productivity in the deep sea, Proc. R. Soc. B., 277, 27832792, 2010.

Doney, S. C. and Jenkins, W. J.: Ventilation of the deep western boundary current and the abyssal western North Atlantic: estimates from tritium and ${ }^{3} \mathrm{He}$ distributions, J. Phys. Oceanogr., 24, 638-659, 1994. 
Duarte, C. M., Hendriks, I. E., Moore, T.S., Olsen, Y. S., Steckbauer, A., Ramajo, L., Carstensen, J., Trotter J. A., and McCulloch, M.: Is Ocean Acidification an Open-Ocean Syndrome? Understanding Anthropogenic Impacts on Seawater $\mathrm{pH}$, Estuar. Coast., 36, 221-236, 2013.

Elderfield, H., Ferretti, P., Greaves, M., Crowhurst, S., McCave, I. N., Hodell, D., and Piotrowski, A.M.: Evolution of Ocean Temperature and Ice Volume Through the Mid-Pleistocene Climate Transition, Science, 337, 704-709, 2012.

Fautin, D. G., Guinotte, J. M., and Orr, J. C.: Comparative depth distribution of corallimorpharians and scleractinians (Cnidaria: Anthozoa), Mar. Ecol. Prog. Ser., 397, 63-70, 2009.

Fleeger, J. W., Carman, K. R., Weisenhorn, P. B., Sofranko, H., Marshall, T., Thistle, D., and Barry, J. P.: Simulated sequestration of anthropogenic carbon dioxide at a deep-sea site: Effects on nematode abundance and biovolume, Deep-Sea Res. Pt. I, 53, 1135-1147, 2006.

Frölicher, T. L. and Joos, F.: Reversible and irreversible impacts of greenhouse gas emissions in multi-century projections with the NCAR global coupled carbon cycle-climate model, Clim. Dyn., 35, 1439-1459, 2010.

Gehlen, M., Bopp, L. and Aumont, O.: The short-term dissolution response of pelagic carbonate sediments to the invasion of anthropogenic $\mathrm{CO}_{2}$ : A model study, Geochem. Geophys. Geosyst., 9, Q02012, doi:10.1029/2007GC001756, 2008.

González-Dávila, M., Santana-Casiano, J. M., Rueda, M. J., and Llinás, O.: The water column distribution of carbonate system variables at the ESTOC site from 1995 to 2004, Biogeosciences, 7, 3067-3081, doi:10.5194/bg-7-3067-2010, 2010.

Guinotte, J. M., Orr, J., Cairns, S., Freiwald, A., Morgan, L., and George, R.: Will human-induced changes in seawater chemistry alter the distribution of deep-sea scleractinian corals? Front. Ecol. Environ., 4, 141-146, 2006.

Harris, P. T. and Whiteway, T.: Global distribution of large submarine canyons: Geomorphic differences between active and passive continental margins, Mar. Geol., 285, 69-86, 2011.

Hendriks, I. E., Duarte, C. M., and Álvarez, M.: Vulnerability of marine biodiversity to ocean acidification: A meta-analysis, Est., Coast. Shelf Sci., 86, 157-164, 2010.

Hofmann, G. E., Smith, J. E., Johnson, K. S., Send, U., Levin, L. A., Micheli, F., Paytan, A., Price, N. N., Peterson, B., Takeshita, Y., Matson, P. G., Crook, E. D., Kroeker, K. J., Gambi, M. C., Rivest, E. B., Frieder, C. A., Yu, P. C., and Martz, T. R.: High-Frequency Dynamics of Ocean pH: A Multi-Ecosystem Comparison, PLoS ONE, 6, e28983, doi:10.1371/journal.pone.0028983, 2011.

Hönisch, B., Ridgwell, A., Schmidt, D. N., Thomas, E., Gibbs, S. J., Sluijs, A., Zeebe, R., Kump, L., Martindale, R. C., Greene, S. E., Kiessling, W., Ries, J., Zachos, J. C., Royer, D. L., Barker, S., Marchitto, T. M., Moyer, R., Pelejero, C., Ziveri, P., Foster, G. L., and Williams, B.: The Geological Record of Ocean Acidification, Science, 335, 1058-1063, 2008.

ICES, Report of the Working Group on Deep-water Ecology 26-28, ICES CM 2007/ACE:01 Ref. LRC, International Council for the Exploration of the Sea, Copenhagen, Denmark, 61 pp., 2007.

IPCC: Workshop Report of the Intergovernmental Panel on Climate Change Workshop on Impacts of Ocean Acidification on Marine Biology and Ecosystems, eds Field CB et al. (IPCC Working Group II Technical Support Unit, Carnegie Institution, Stanford, California, United States of America), 164 pp., 2011.
Jones, D. O. B., Yool, A., Wei, C.-L., Henson, S. A., Ruhl, H. A., Watson, R. A., and Gehlen, M.: Global reductions in seafloor biomass in response to climate change, Glob. Change Biol., 20, 1864-1873, doi:10.1111/gcb.12480, 2014.

Khatiwala, S., Tanhua, T., Mikaloff-Fletcher, S., Gerber, M., Doney, S. C., Graven, H. D., Gruber, N., McKinley, G. A., Murata, A., Ríos, A. F., and Sabine, C. L.: Global ocean storage of anthropogenic carbon, Biogeosciences, 10, 2169-2191, doi:10.5194/bg-10-2169-2013, 2013.

Kroeker, K. J., Kordas, R. L., Crim, R. N., and Singh, G. G.: Metaanalysis reveals negative yet variable effects of ocean acidification on marine organisms, Ecol. Lett., 13, 1419-1434, 2010.

Marchal, O., Stocker, T. F., Joos, F., Indermühle, A., Blunier, T., and Tschumi, J: Modeling the concentration of atmospheric $\mathrm{CO}_{2}$ during the Younger Dryas climate event, Clim. Dynam., 15, 341354, 1999.

Matsumoto, K. and Yokoyama, Y.: Atmospheric $\Delta^{14}$ Creduction in simulations of Atlantic overturning circulation shutdown, Global Biogeochem. Cy., 27, 296-304, 2013.

Meehl, G. A., Stocker, T. F., Collins, W. D., Friedlingstein, P., Gaye, A. T., Gregory, J. M., Kitoh, A., Knutti, R., Murphy, J. M., Noda, A., Raper, S. C. B., Watterson, I. G., Weaver, A. J., and Zhao, Z.-C.: Global Climate Projections, in: Climate Change 2007: The Physical Science Basis. Contribution of Working Group I to the Fourth Assessment Report of the Intergovernmental Panel on Climate Change, edited by: Solomon, S., Qin, D., Manning, M., Chen, Z., Marquis, M., Averyt, K. B., Tignor, M., and Miller, H. L., Cambridge University Press, Cambridge, United Kingdom and New York, NY, USA, 2007.

Mora, C., Wei, C.-L., Rollo, A., Amaro, T., Baco, A. R., et al.: Biotic and Human Vulnerability to Projected Changes in Ocean Biogeochemistry over the 21st Century, PLoS Biol, 11, e1001682, doi:10.1371/journal.pbio.1001682, 2013.

Moss, R. H., Edmonds, J. A., Hibbard, K. A., Manning, M. R., Rose, S. K., van Vuuren, D. P., Carter, T. R., Emori, S., Kainuma, M., Kram, T., Meehl, G. A., Mitchell, J. F. B., Nakicenovic, N., Riahi, K., Smith, S. J., Stouffer, R. J., Thomson, A. M., Weyant, J. P., and Wilbanks, T. J.: The next generation of scenarios for climate change research and assessment, Nature, 463, 747-756, 2010.

Orr, J. C.: Recent and future changes in ocean carbonate chemistry, in: Ocean Acidification, edited by: Gattuso, J.-P. and Hansson, L., Oxford University Press, Oxford, 41-66, 2011.

Orr, J. C., Fabry, V. J., Aumont, O., Bopp, L., Doney, S. C., Feely, R. A., Gnanadesikan, A., Gruber, N., Ishida, A., Joos, F., Key, R. M., Lindsay, K., Maier-Reimer, E., Matear, R., Monfray, P., Mouchet, A., Najjar, R. G., Plattner, G.-K., Rodgers, K. B., Sabine, C. L., Sarmiento, J. L., Schlitzer, R., Slater, R. D., Totterdell, I. J., Weirig, M.-F., Yamanaka, Y., and Yool, A.: Anthropogenic ocean acidification over the twenty-first century and its impact on calcifying organisms, Nature, 437, 681-686, 2005.

Ramirez-Llodra, E.: Fecundity and life-history strategies in marine invertebrates, Advances in Marine Biology, 43, 87-170, 2002.

Ramirez-Llodra, E., Tyler, P. A., Baker, M. C., Bergstad, O. A., Clark, M. R., Escobar, E., Levin, L. A., Menot, L., Rowden, A. A., Smith, C. R., and Van Dover, C. Ø.: Man and the Last Great Wilderness: Human Impact on the Deep Sea, PLoS ONE, 6, e22588, doi:10.1371/journal.pone.0022588, 2011.

Roth, R. and Joos, F.: A reconstruction of radiocarbon production and total solar irradiance from the Holocene ${ }^{14} \mathrm{C}$ and $\mathrm{CO}_{2}$ 
records: implications of data and model uncertainties, Clim. Past, 9, 1879-1909, doi:10.5194/cp-9-1879-2013, 2013.

Sabine, C. L., Feely, R. A., Gruber, N., Key, R. M., Lee, K., Bullister, J. L., Wanninkhof, R., Wong, C. S., Wallace, D. W. R., Tilbrook, B., Millero, F. J., Peng, T.-H., Kozyr, A., Ono, T., and Rios, A. F.: The oceanic sink for anthropogenic $\mathrm{CO}_{2}$, Science, 305, 367-371, 2004.

Sanyal, A., Hemming, N. G., Hanson, G. N., and Broecker, W. S.: Evidence for a higher $\mathrm{pH}$ in the glacial ocean from boron isotopes in foraminifera, Nature, 373, 234-236, 1995.

Schubert, R., Schellnhuber, H.-J., Buchmann, N., Epiney, A., Griesshammer, R., Kulessa, M., Messner, D., Rahmstorf, S., and Schmid, J. : The future oceans - Warming up, rising high, turning sour, Special Report by the German Advisory Council on Global Change (WBGU), 123 pp., 2006.

Schwinger, J., Tjiputra, J. F., Heinze, C., Bopp, L., Christian, J. R., Gehlen, M., Ilyina, T., Jones, C. D., Salas-Mélia, D., Segschneider, J., Séférian, R., and Totterdell, I.: Non-linearity of ocean carbon cycle feedbacks in CMIP5 earth system models, J. Climate, 27, 3869-3888, 2014.

Seibel, B. A. and Walsh, P. J.: Potential Impacts of $\mathrm{CO}_{2}$ Injection on Deep-Sea Biota, Science, 294, 319-320, 2001.

Seibel, B. A. and Walsh, P. J.: Biological impacts of deep-sea carbon dioxide injection inferred from indices of physiological performance, J. Experim. Biol., 206, 641-650, 2003.

Somero, G. N.: The Physiology of Global Change: Linking Patterns to Mechanisms, Annu. Rev. Mar. Sci., 4, 39-61, 2012.

Steinacher, M., Joos, F., and Stocker, T. F.: Allowable carbon emissions lowered by multiple climate targets, Nature, 499, 197-201, 2013.

Taranto, G. H., Kvile, K. Ø., Pitcher, T. J., and Morato, T.: An Ecosystem Evaluation Framework for Global Seamount Conservation and Management, PLoS ONE, 7, e42950, doi:10.1371/journal.pone.0042950, 2012.
Taylor, K. E., Stouffer, R. J., and Meehl, G. A.: An overview of CMIP5 and the experiment design, Bull. Am. Meteor. Soc., 93, 485-498, doi:10.1175/ BAMS-D-11-00094, 2011.

Tittensor, D. P., Baco A. R., Hall-Spencer, J. M., Orr, J. C., and Rogers, A. D., Seamounts as refugia from ocean acidification for coldwater stony corals, Mar. Ecol., 31, 212-225, 2010.

Turley, C. M., Roberts, J. M., and Guinotte, J. M.: Corals in deepwater: Will the unseen hand of ocean acidification destroy coldwater ecosystems?, Coral Reefs, 26, 445-448, 2007.

Van Vuuren, D. P., Edmonds, J., Kainuma, M., Riahi, K., Thomson, A., Hibbard, K., Hurtt, G. C., Kram, T., Krey, V., Lamarque, J.F., Masui, T., Meinshausen, M., Nakicenovic, N., Smith, S. J., and Rose, S. K.: The representative concentration pathways: an overview, Clim. Change., 109, 5-31, 2011.

Walther, K., Sartoris, F. J., Bock, C., and Pörtner, H. O.: Impact of anthropogenic ocean acidification on thermal tolerance of the spider crab Hyas araneus, Biogeosciences, 6, 2207-2215, doi:10.5194/bg-6-2207-2009, 2009.

Widdicombe, S. and Spicer, J. I.: Predicting the impact of ocean acidification on benthic biodiversity: What can physiology tell us?, J. Exp. Mar. Biol. Ecol., 366, 187-197, 2008.

Yesson, C., Clark, M. R., Taylor, M. L., and Rogers, A. D.: The global distribution of seamounts based on 30 arc seconds bathymetry data, Deep-Sea Res. I, 58, 442-453, 2011.

Yu, J., Broecker, W. S., Elderfield, H., Jin, Z., McManus, J., and Zhang, F.: Loss of Carbon from the Deep Sea Since the Last Glacial Maximum, Science, 330, 1084-1087, 2010.

Yu, J., Anderson, R. F., Jin, Z., Rae, J. W. B., Opdyke, N., and Eggins, S. M.: Responses of the deep ocean carbonate system to carbon reorganization during the Last Glacial-interglacial cycle, Quat. Sci. Rev., 76, 39-52, 2013. 